\title{
Floating Charge Debenture as Security from Sharì'ah Perspective
}

\author{
Syairazi Muhammad Husni Mohd Sharoni (1), Rusni Hassan (2)
}

\begin{abstract}
Floating charge debenture is one type of security adopted by the Islamic Banks in Malaysia for non-individual customers. For Islamic banks, it is crucial to ensure that all of their banking products and services are Sharíah compliant. However, there is no specific ruling from Bank Negara Malaysia on Sharīah compliance status of floating charge debenture. Therefore, the purpose of this paper is to determine the soundness of floating charge debenture as security by Islamic banks in Malaysia from the Shari' ah perspective. This paper adopted a qualitative method that referred to primary and secondary Sharī ah sources, as well as other related sources such as guidelines of Bank Negara Malaysia and Accounting and Auditing Organization for Islamic Financial Institution. The paper found that it is permissible for an Islamic bank to accept floating charge debenture from non-individual customers as security with certain conditions. This paper suggests that the Bank Negara Malaysia should issue certain resolution related to this issue to arrange related applications in Islamic banks in Malaysia.

Keywords: Debenture, Floating Charge, Security, Sharī ah Compliance, Islamic Bank

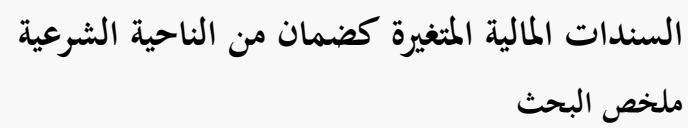

تعتبر السندات المالية المتغيرة إحدى أنواع الضمانات التي تبنتها المصارف الإسلامية في ماليزيا للشركات. فلا بد للمصارف الإسلامية أن تتأكد في كل منتجامَا وخدماتما موافقة الأحكام الشرعية. ولكن، هناك لا يوجد قرار معين من جانب بنك ماليزيا المركزي عن مشروعية السندات المالية المتغيرة

كضمان. ولذا يهدف هذا البحث إلى تحقيق صحة ممارسة السندات المالية المتغيرة كضمان للمصارف الإسلامية في ماليزيا من وجهة النظر الشرعية.

وقد تم استخدام المنهج النوعي المتمثل في المصادر الشرعية الأصلية والثانوية والمصادر الأخرى المتعلقة بالموضوع كإشادات بنك ماليزيا المركزي وهيئة المحاسبة والمراجعة للمؤسسات المالية الإسلامية (أيوفي). وبناء على نتائج هذا البحث، يجوز للمصارف الإسلامية أن تقبل السندات المالية المتغيرة من

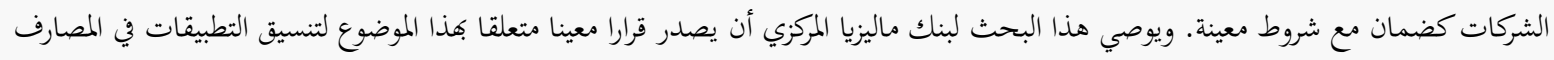
الإسلامية في ماليزيا.

كلمات مفتاحية: السندات المالية، المتغيرة، الضمان، موافقة الثرع، المصرف الإسلامي

(1) Phd., Institute of Islamic Banking \& Finance (IIiBF), International Islamic University Malaysia. syaihusni@ gmail.com

(2) Professor, Institute of Islamic Banking \& Finance (IIiBF), International Islamic University Malaysia. hrusni@iium.edu.my
\end{abstract}

\section{Contents}

Introduction

1.1 Background

1.2 Significant of the Study

1.3 Research Methodology

Literature Review

2.1 Rahn from Shariah Perspective

2.2 Type of Debenture

2.3 Comparison between Rahn and Debenture

Problem Statement

Shariah Analysis

4.1 First Group

4.2 Second Group

4.3 Preferred Opinion (Tarjīh)

4.4 Fiqh Adaption (Takyīf Fiqhī)

Conclusion

References

\section{Introduction}

\subsection{Background:}

Banking business is exposed to many types of risks such as liquidity risk, legal risk and market risk. Moreover, Islamic banks are also exposed to special risks such as rate of return risk, displaced commercial risk, Shariah non-compliance risk and equity investment risk. Giving financing to the customer as the main banking business requires Islamic banks to have a robust credit risk management.

Credit risk is the utmost challenge for the Islamic bank to ensure their survival in the market. Thus, Islamic bank must put a big effort to ensure the sustainability of the company. Other than that, a proper management on collection and recovery should be established. Size of asset and low Non-Performing 
Financing (NPF) is the determinant of the stability of the Islamic bank.

Due to the significance of credit risk management, the Board of Director (BOD) carries a significant role in approving and monitoring the internal control and credit risk strategies applied in the Islamic bank. The strategies should reflect the Islamic bank's risk appetite and the level of expected profit to be achieved (The Basel Committe, 2006). Furthermore, the credit risk management should also consider the practise of recovery and rehabilitation of the banking institutions. Failure of the Islamic bank to recover their capital may arise from the unsuitable security requested from the customer.

Among the type of security that can be taken by the Islamic bank is debenture. According to (Mohammad Yusoff, 2002) the main benefit of having a debenture is, the recovery process is effectively faster, without having to go through the normal legal process. Islamic banks can appoint receiver managers to sale the charged asset including the landed property on a private treaty without going through the judicial sale.

This paper aims to validate the practise of floating charge debenture as security in Islamic banking in Malaysia from the Shariah perspective. In specific, it focuses on suggesting the figh adaptation (takyīf fiqhī) of floating charge debenture in line with Rahn contract. Some recommendations from this paper will be addressed to ensure the practise of debenture as security is Shariah compliant.

\subsection{Significant of The Study:}

One of the main reasons why floating charge came into existence is to allow companies to buy and sell business inputs and stocks without affecting their day-to-day operations. They can obtain funding by keeping a charge on their inventories as collateral without interrupting their business operations (E Finance Management, n.d.).

On the other hand, the floating charge also facilitates the financier in increasing the limit of financing for revolving products. For instance, initially, the Islamic bank A grants financing of Trade Working Capital Financing-i (TWCF-i) or Cashline-i to Customer B with a limit of RM 1 million. If the Islamic bank A takes fixed charge security from Customer B which equivalent to RM1 million, the Islamic bank A will not increase the financing limit without entry into a new security agreement. However, if the Islamic bank A took the floating charge for security, they can easily increase the financing limit without the need for additional security agreement since the floating charge already covers all assets of Company B. In fact, floating charge can be created even when the company does not have any fixed asset.

\subsection{Research Methodology:}

This paper adopts the qualitative method that will explore and understand the nature of secured floating charge debenture and provide the Shariah point of view which will refer to classical and modern Scholars' opinions. Additionally, this paper also uses references from library research which include books, theses, journals, magazines and other related academic writing.

Not only that, this paper also refers to Bank Negara Malaysia (BNM)'s resolutions and Accounting and Auditing Organization for Islamic Financial Institution (AAOIFI)'s resolutions to observe regulators' perspective on the floating charge debenture. This paper only focuses on regulators' requirement on Rahn based-products. Although AAOIFI Shariah Standards on Rahn is not a requirement in Malaysia, however, it is covered in a lot of discussions of Rahn in contemporary Islamic banking operation.

\section{Literature Review}

\subsection{Rahn from Shariah Perspective}

\subsubsection{Definition of Rahn:}

Rahn is one of the nominated contracts (al- 'uqūd almusamma) which are known amongst the scholars, mentioned in classical fiqh literature and precisely explained based on the primary sources of rulings namely Al-Qurān and Al-Hadīth. In fact, it is a contract which was already practiced before Islam.

Literally, Rahn can be defined as evidence, endure, seizure, restrain and establish (Mustafā, Qādir, Ziyāt, \& Najjār, 2004). Al-Ma'anī (n.d.)'s dictionary also defines Rahn as claim on (property) as a security 
for payment of a debt or loan or the amount of money you owe on a pledge.

From a technical definition, Rahn is defined as making a financial asset or so tied to a debt so that the asset or its value is used for repayment of the debt in case of default (AAOIFI, 2015). In pre-Islamic Arab usage, Rahn 'security' means a kind of earnest money which was given as a guarantee and material proof for a contract particularly when there was no scribe available to put it into writing (Schacht, 1950).

\subsubsection{Pillars and Conditions of Rahn:}

In Shariah, it is essential to understand the pillars of the contract. There are five pillars of the Rahn contract namely sighah (the offer and acceptance to enter into the Rahn contract), rāhin (pledgor or party that provides the pledge asset), murtahin (pledgee or party that holds the pledge asset), marhūn (pledged asset where the subject matter of the Rahn contract where the asset is pledged to the pledgee) and marhün bih (obligation which is the debt owed by the rāhin to the murtahin). Essentially, Rahn has existed before Islam (Hussīn, 2013) and Prophet Muhammad (PBUH) did not prohibit it during his time. In Islam, the practice of Rahn is permissible and its legality is based on the AlQurān and Al-Hadīth. In Al-Qurān Allah said that:

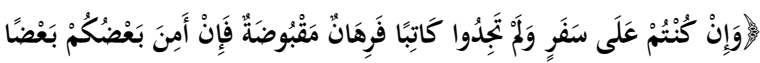

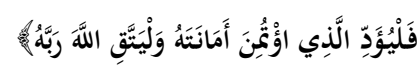

"And if you are on a journey and cannot find a scribe, then let there be a pledge taken (mortgaging); then if one of you entrust the other, let the one who is entrusted discharge his trust (faithfully), and let him be afraid of Allah, his Lord". [Al-Baqarah: 283]

Literal understanding from the above verse is that a pledge is only allowed when the transaction is executed during travel or when there is absence of witnesses to write down the debt. It is concluded that travel and the absence of witnesses are the conditions for the pledge to be valid. This is referring to Ibn Hazm Az-Zāhirī’s opinion.

On the other hand, majority of the scholars do not consider travel and the absence of witnesses as the conditions for the Rahn contract to be valid. They allow Rahn to be executed during travel or not in travel even with the presence of witnesses. Majority of the scholars allow this practice based on the Al-Hadith where the Prophet (PBUH) pledged his armour to the Jews while he was not in travel (Musa, 2008) as the Al-Hadith below mentions:

It narrated from 'A'ishah, she said that:

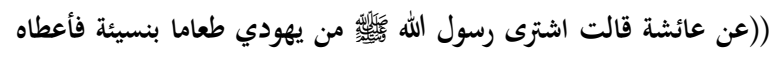

"The Prophet bought some foodstuff on credit from a Jew and pledged an iron armour to him”. [Muslim, Kitab Al-Musāqāt, No. 1603]

Based on the mentioned Al-Qurān verse and AlHadith, the practice of pledge is allowed based on the permissibility ('ibāhah) and not on the obligatory (wäjib) since the verse is related to daily human activities. These commands show that it is permissible for Muslims to pledge their assets to secure the creditor's interest.

Furthermore, classical Scholars (Al-Yamānī, 2000) and (Mansuri, 2007) also mentioned that there are some conditions to be fulfilled to ensure Rahn contract is valid which are divided into three categories whichare for contracting parties (rāhin \& murtahin), pledged asset (marhūn) and the obligation (marhūn bih).

For contracting parties, both pledgor and pledgee should have receptive legal capacity ('ahalliyat al-wujūb) and active legal capacity ('ahallīyat al- 'adā') where both parties should be a competent person who fulfils some conditions which are having prudence ('aāqil) and age of maturity (bāligh). Then, to ensure the contract is valid, Rahn contract must be developed by mutual consent between pledgor and pledgee which can be shown through contractual expressions (sighah) which are offer ('ijjab) and acceptance (qabūl). There are two conditions for contractual expressions to be valid namely, they should be clear and there should be consent from both parties. Consent also cannot be obtained through defective means, such as by duress ('ikrāh), fraud (tadlīs) or unfairness/ manipulation (ghabn).

In terms of the pledged asset (marhūn), it should be an asset that has some monetary worth and legal value. For sure, the asset should be permissible by the 
Shariah. Thus, it is prohibited to pledge nonpermissible assets such as pork and wine.

Other than that, there are some specific conditions for marhün bih (obligation) where it should be an established and enforceable debt. Thus, a pledge may be given for loan, price in credit sale, commodity of salām contract, claim after usurpation, damages in the torts against property, amount of dower, blood money and all the other binding and irrevocable claims. Therefore, a pledge is not permitted for the things for which there is no liability of compensation such as deposits, commodate loans, capital of mudārabah and mushärakah partnerships, leased property in the hands of lessee.

Not only that, the obligation should be compliant with the Shariah. For example, it is not permissible to give a pledge for the remuneration of a dancer or singer because hiring a woman to dance or sing is an invalid and impermissible act. Then, the claim or debt should be known and defined. Thus, it is not permissible to give something as security for one of the two loans without specifying one of them.

\subsection{Type of Debenture}

\subsubsection{Fixed \& Floating Charge Debenture:}

Generally, a secured debenture is a debenture that is secured by a fixed or floating charge on the assets of the company. The fixed charge is a charge over a particular asset where the chargee controls any dealing or disposal of the asset by the chargor. A fixed charge ranks before a floating charge in the order of repayment on an insolvency (Thomson Reuters, n.d.-a). When a charge is created, the company cannot sell that property without the consent of the holder of the charge.

The latter is a floating charge where a charge takes over all the assets or a class of assets owned by a company or a limited liability partnership from time to time as security for borrowings or other indebtedness (Thomson Reuters, n.d.-b). It means the charge covers not only the present assets of the company but also covers the future assets of the company. Contrary to the fixed charge, an asset that has been charged under floating charge still can be sold by the company with the condition that it must be replaced with a new asset.
However, this paper will only focus on the floating charge debenture to analyse the permissibility and Shariah basis of floating charge secured debenture.

\subsubsection{Floating Charge:}

To understand the characteristic of the floating charge, Field Fisher Waterhouse (2011) stated that, there are three main characteristics of floating charge that are: the charge is over all of a class of assets of the borrower, present and future, the assets in the class change from time to time in the ordinary course of the borrower's business; and the borrower is free to deal with the assets in the ordinary course of its business without the consent of the lender, until some steps are taken or an event occurs which "crystallises" the charge.

Although the first two characteristics of the floating charge can be also applicable to a fixed charge, the third characteristic is only applicable to the floating charge. Theoretically, the main distinction between the fixed and floating charges can be easily seen by the level of freedom and control over the charged assets by the pledgor (Zhuravel, 2015).

Even though a fixed charge is more preferred in terms of security, floating charge becomes a substantial security where a company cannot provide any fixed assets. Another advantage of the floating charge is the company can use the asset as security and at the same time they can use or sell the asset. It means that the pledgor is free to deal with the asset without a need to get the pledgee's consent to sell it. This offers the business owner more freedom. To protect the creditor's interest, the floating charge will be attached to the entire asset of the borrower.

Meanwhile, the floating charge also has some disadvantages or weaknesses where it is less attractive to the pledgee as the financing granted has a higher risk compared to the fixed charge (Zhuravel, 2015). The creditor also needs to bear the market risk since the value of the asset may increase or decrease. As stated in Section 392 in Companies Act 2017 (Government of Malaysia, 2016), during liquidation process, the floating charge will be set aside not only to a fixed charge but also to other type of debts such as liquidation fee, salaries, remuneration payable and takaful contribution. 
Regardless of all the disadvantages mentioned above, this paper opined that being a floating charge debenture holder is more secure than an unsecured creditor.

\subsection{Comparison between Rahn and Debenture}

This part will make a comparison between Rahn and debenture as security to evaluate whether Rahn and debenture as security are having the same elements. The comparison is based on main elements in both Rahn and debenture as security which are its definition, type, a party that provides security, contractual obligation, conditions, bindingness and reference. The details are explained in the table below:

\begin{tabular}{|c|c|c|c|}
\hline Item & Rahn & $\begin{array}{c}\text { Debenture as } \\
\text { Security }\end{array}$ & Remark \\
\hline 1. Definition & $\begin{array}{l}\text { Make a financial } \\
\text { asset or so tied to } \\
\text { a debt so that the } \\
\text { asset or its value } \\
\text { is used for } \\
\text { repayment of the } \\
\text { debt in case of } \\
\text { default. }\end{array}$ & $\begin{array}{l}\text { A security } \\
\text { document that is } \\
\text { usually entered } \\
\text { into when } \\
\text { creating a fixed } \\
\text { and floating } \\
\text { charge over the } \\
\text { assets and } \\
\text { undertaking of a } \\
\text { borrower. }\end{array}$ & $\begin{array}{l}\text { Both } \\
\text { definitions } \\
\text { aim to } \\
\text { safeguard } \\
\text { the interest } \\
\text { of the } \\
\text { person who } \\
\text { provides } \\
\text { the debt. }\end{array}$ \\
\hline 2. Type & $\begin{array}{l}\text { Two main types: } \\
\text { Rahn hiyāz } \bar{\imath} \\
\text { (pledge of } \\
\text { physical } \\
\text { possession) and } \\
\text { Rahn ta'aminni } \\
\text { (pledge of } \\
\text { constructive } \\
\text { possession). }\end{array}$ & $\begin{array}{l}\text { Two main types: } \\
\text { Secured and } \\
\text { unsecured. } \\
\text { Secured is } \\
\text { divided into } \\
\text { fixed charge and } \\
\text { floating charge. }\end{array}$ & $\begin{array}{l}\text { No specific } \\
\text { relation } \\
\text { where Rahn } \\
\text { is classified } \\
\text { by method } \\
\text { of } \\
\text { possession, } \\
\text { meanwhile, } \\
\text { debenture is } \\
\text { classified } \\
\text { by avilability } \\
\text { of charged } \\
\text { asset and } \\
\text { restriction } \\
\text { of the } \\
\text { owner in } \\
\text { dealing } \\
\text { with } \\
\text { charged } \\
\text { asset. }\end{array}$ \\
\hline $\begin{array}{l}\text { 3. Party that } \\
\text { provide } \\
\text { securities }\end{array}$ & $\begin{array}{l}\text { The debtor itself } \\
\text { or third party }\end{array}$ & The debtor itself & $\begin{array}{l}\text { In principle, } \\
\text { both debtor } \\
\text { and issuer } \\
\text { should } \\
\text { provide the } \\
\text { security. } \\
\text { However, it } \\
\text { is allowed } \\
\text { for third } \\
\text { party to } \\
\text { provide the } \\
\text { asset for } \\
\text { Rahn. }\end{array}$ \\
\hline $\begin{array}{l}\text { 4. Contractual } \\
\text { Obligation }\end{array}$ & $\begin{array}{l}\text { Assurance that } \\
\text { the marhün bih } \\
\text { (liability or } \\
\text { obligation) owed } \\
\text { by the obligor to } \\
\text { the pledgee will } \\
\text { be fulfilled in the } \\
\text { event of a default } \\
\text { as agreed in the } \\
\text { terms and } \\
\text { conditions of } \\
\text { Rahn. }\end{array}$ & $\begin{array}{l}\text { A certificate } \\
\text { evidencing the } \\
\text { fact that the } \\
\text { company is } \\
\text { liable to pay a } \\
\text { specified } \\
\text { amount to the } \\
\text { debenture } \\
\text { holder. }\end{array}$ & $\begin{array}{l}\text { Rahn is a } \\
\text { type of } \\
\text { contract } \\
\text { that can be } \\
\text { developed } \\
\text { into a } \\
\text { product. } \\
\text { Debenture } \\
\text { is a product } \\
\text { that is based } \\
\text { on Rahn } \\
\text { contract. }\end{array}$ \\
\hline
\end{tabular}

\begin{tabular}{|c|c|c|c|}
\hline \multirow[t]{8}{*}{ 5. Condition } & $\begin{array}{lr}\text { Contracting } & \\
\text { parties: } & \text { rāhin } \\
\text { (pledgor) } & \text { and } \\
\text { murtahin } & \\
\text { (pledgee). } & \end{array}$ & $\begin{array}{l}\text { Contracting } \\
\text { parties: Issuer } \\
\text { and debenture } \\
\text { holder. }\end{array}$ & $\begin{array}{l}\text { Same } \\
\text { condition. }\end{array}$ \\
\hline & $\begin{array}{l}\text { Ijab and qabūl in } \\
\text { Rahn contract. }\end{array}$ & $\begin{array}{lr}\text { Offer } & \text { and } \\
\text { acceptance } & \text { in } \\
\text { Debenture } & \\
\text { agreement. } & \\
\end{array}$ & $\begin{array}{l}\text { Same } \\
\text { condition. }\end{array}$ \\
\hline & $\begin{array}{l}\text { Marhūn (pledged } \\
\text { asset). }\end{array}$ & $\begin{array}{l}\text { Fixed and } \\
\text { floating charged } \\
\text { asset. }\end{array}$ & $\begin{array}{l}\text { Same } \\
\text { condition. }\end{array}$ \\
\hline & $\begin{array}{l}\text { Requirement for } \\
\text { pledged asset: } \\
\text { The asset must be } \\
\text { a māl } \\
\text { mutaqawwam } \\
\text { which is an asset } \\
\text { that has } \\
\text { commercial value } \\
\text { and } \\
\text { Shariah } \\
\text { compliance asset. }\end{array}$ & $\begin{array}{l}\text { Requirement for } \\
\text { charged asset: } \\
\text { Any assets that } \\
\text { have } \\
\text { commercial } \\
\text { value. }\end{array}$ & $\begin{array}{l}\text { Shariah has } \\
\text { an } \\
\text { additional } \\
\text { requirement } \\
\text { which the } \\
\text { asset must } \\
\text { not be a } \\
\text { prohibited } \\
\text { asset. }\end{array}$ \\
\hline & $\begin{array}{ll}\text { Marhūn } & \text { bih } \\
\text { (obligation). } & \end{array}$ & $\begin{array}{l}\text { Financing } \\
\text { granted by } \\
\text { Islamic bank. } \\
\end{array}$ & $\begin{array}{l}\text { Same } \\
\text { condition. }\end{array}$ \\
\hline & $\begin{array}{l}\text { Possession of } \\
\text { marhūn (pledged } \\
\text { asset). }\end{array}$ & $\begin{array}{l}\text { Registration of } \\
\text { charge. }\end{array}$ & $\begin{array}{l}\text { Same } \\
\text { condition. }\end{array}$ \\
\hline & $\begin{array}{l}\text { Dissolution } \\
\text { (fasakh) of Rahn. }\end{array}$ & $\begin{array}{ll}\text { Destruction } & \text { or } \\
\text { disposal } & \text { of } \\
\text { charged asset. } & \\
\end{array}$ & $\begin{array}{l}\text { Same } \\
\text { condition. }\end{array}$ \\
\hline & $\begin{array}{l}\text { Completion } \\
\text { ('intiha')' } \\
\text { Rahn. }\end{array}$ & $\begin{array}{l}\text { Release of } \\
\text { charge by } \\
\text { settlement of the } \\
\text { financing or } \\
\text { liquidation of } \\
\text { asset. }\end{array}$ & $\begin{array}{l}\text { Same } \\
\text { condition. }\end{array}$ \\
\hline 6. Bindingness & $\begin{array}{l}\text { Binding on the } \\
\text { pledgor. }\end{array}$ & $\begin{array}{l}\text { Binding on the } \\
\text { issuer. }\end{array}$ & $\begin{array}{l}\text { Same } \\
\text { condition. }\end{array}$ \\
\hline 7. Reference & Islamic Law. & $\begin{array}{l}\text { Subdivision 10, } \\
\text { Division 1, Part } \\
\text { III of Companies } \\
\text { Act. However, } \\
\text { another related } \\
\text { Section may } \\
\text { apply. }\end{array}$ & $\begin{array}{l}\text { Ruling of } \\
\text { Rahn is } \\
\text { from divine } \\
\text { sources and } \\
\text { debenture is } \\
\text { enacted by } \\
\text { human. }\end{array}$ \\
\hline
\end{tabular}

Based on the table above, this paper found that Rahn and debenture as security are having same elements where both aim to protect the interest of the person who provides the debt. In the event of default, charged asset will be liquidated to pay the debtor. Then, contractual obligation further establishes that Rahn is a type of Shariah contract that can be illustrated in a modern financial product. From the Shariah point of view, debenture as security is one type of modern collateral that is based on the Rahn contract. Then, there are 7 main conditions in Rahn where its elements are the same with debenture as security where Shariah requirements on Rahn were translated into modern terminology in debenture as security. In terms of bindingness, both are binding on the creditor which is the issuer and the pledgor.

Even though there is a difference between Rahn and debenture in term of its classification, it is just varying in the structure without affecting the 
contractual obligation. In terms of the party that provides the security, the security for debenture is provided by the debtor itself while security for Rahn can be provided by the debtor or a third party. Basically, the main difference between Rahn and debenture as security is the way they are inherited from their reference. The Shariah rule for Rahn is derived from the divine sources which are the Al-Qurān and the Al-Hadīth. Meanwhile, debenture is governed by a legal act specifically by Subdivision 10, Division 1, Part III of Companies Act 2016 that is enacted by human beings. Another related section in this Act may apply by case to case basis. This act is open to changes from time to time to make it suitable and relevant with modern practice.

\section{Problem Statement}

Due to the open-ended practise of the floating charge debenture as security, it is very difficult to find any specific figh resolution on debenture.

Moreover, the practice of Rahn as mentioned by classical Scholars is different from modern banking practice. Not only that, contemporary scholars do not widely discuss about debenture as security and its compliance with Shariah law. To resolve the issue, this paper will discuss the practice of floating charge debenture as security in Islamic banking from a Shariah perspective.

\section{Shariah Analysis}

Based on the analysis conducted, this research found that there are some Shariah issues to be discussed. Among the issues are pledged assets to be owned in the future, uncertainty in pledged assets, multiple charges on one asset and pledge of joint undivided assets. This research classifies the opinion into two groups. The first group is those who prohibit the practice of floating charge debenture while the second group is those who allow that practice.

\subsection{First Group:}

\section{Pledged Asset to Be Owned in the Future:}

The issue of floating charge debenture is the pledgor may pledge an asset that is yet to be owned. Normally, this happens when the pledgor pledges any asset that will be realised in the future such as rental payment and others receivable. Even though the rental is yet to be realized, it is already considered a pledged asset.

In this case, the first group said that it is not allowed to pledge because at the time of the pledge of the asset, he is not the owner of the asset (Al-Yamānī, 2000).

\section{Uncertainty in the Pledged Asset (Gharar fĩ Al- Marhūn):}

In floating charge debenture, there is the situation where the asset is not properly identified and tagged since the pledgor just gives the consent to take his entire asset when he defaults. Pledgor is free to sell the pledged asset, and all the new assets that will be in the ownership of the pledgor will automatically to be pledged as well. A concern arose whether it is allowed to pledge an unknown asset that is not mentioned in the pledge contract during the inception of the pledge contract. Majority of the scholars are in the opinion that it is not permissible to pledge an unknown asset (AlMa’amūrī, 2015).

In specific, floating charge assets involve a few uncertainties such as uncertainty in the type of asset (gharar bi al-jins) where the nature of the asset is not specifically determined; uncertainty in the location of the asset (gharar bi al-makān) where the location of the asset is not specified and uncertainty in the value of the asset (gharar bi al-thaman) where the floating charged asset may involve both marketable and non marketable assets.

\section{Multiple Charges on One Asset:}

Among the justification to disallow the practice of multiple charges on one asset is that not all assets can be divided equally such as animals, shirts and tables. Moreover, the process of division itself will cause damage to the assets. Based on the opinion of Shāfī School (Al-Yamān̄̄, 2000), they intend to forbid multiple charges on one asset since the division of joint assets will decrease the value of the assets. 


\section{Pledge of Joint Undivided Asset (Rahn Al- Mushā'):}

Scholars from Hanafi School such as Abū Hanīfah, Abū Yūsuf, Muhammad As-Syaybān̄̄ \& Zufar (AtTāhūnī, 1997), are in the view that a pledged joint asset is not permissible whether it can be divided or cannot be divided. They are in the opinion that the condition of possession in a pledged asset will be precluded in a joint undivided asset.

\subsection{Second Group:}

\section{Pledged Asset to Be Owned in the Future:}

A classic example of this issue is where a person is the custodian of his father's asset and subsequently, he pledges the asset before the death of his father. The second opinion says this is allowed because after his father is dead, he is the heir and the beneficiary of his father's asset; he is now the owner of the asset (AlYamān̄̄, 2000).

In addition, (Ibnu Taymīyyah \& Ibnu Qayyīm al-Jawzī, 1928) view that, sale transaction on nonexistent asset is allowed with the condition that the seller can deliver the asset at the specific agreed time. Based on these views, Rahn on non-existent asset is allowed with the condition that the principal asset is identified, clearly tagged and there is no possibility of failure by debtor in providing the asset during liquidation.

Shariah Advisory Council of BNM in their $174^{\text {th }}$ meeting on 28 February 2017 (Shariah Advisory Council BNM, 2017) ruled that an asset that will exist in the future may be pledged as collateral. This is based on Rahn as a supporting contract and gharar (uncertainty) in supporting contracts is more tolerable as opposed to exchange contracts. Furthermore, it is an obligation for a debtor to pay the debt even without any collateral. Therefore, having an asset as collateral even in the form of uncertainty is better than not having one. This is based on the justification by Malīkī 's jurists which state that; "something in general is better than nothing". Then, the benefits to the parties from the practice of a pledged asset that will exist in the future far outweigh the possible harms to them.

\section{Uncertainty in Pledged Asset (Gharar fi Al- Marhūn):}

Even so, Malīkī School (Shīkh 'Ahmad Ashāwī, 1995), has a more lenient opinion where they allow pledging any uncertainty-asset with the condition that the uncertainty is minor. But, if there is major uncertainty on the pledged asset, it is not allowed.

Referring to AAOIFI's (2015) Shari'ah Standard No. (31): Controls on Gharar in Financial Transactions, Section 6/1 Impact of Gharar on Rahn; Rahn can permissibly involve a degree of gharar that is not allowed in sale. The ruling that gharar does not affect Rahn contracts is based on the fact that the Rahn contract is not meant in itself, since it is a corollary contract signed for documentation.

Hammād (2009) also mentioned that, the uncertainty in the supporting contract is forgiven based on the opinion of 'Imām An-Nawāwī, Ibnu Qudāmah and Ibnu Qayyīm Al-Jawzī. Therefore, the uncertainties involved in floating charge debenture do not contradict with Shariah rules and principles since it is stipulated in a supporting contract and not in the main financing contract.

\section{Multiple Charges on One Asset:}

Based on the opinion of the Shāfī̄ School (Al-Yamānī, 2000), if a person has a debt with two creditors, it is allowed for him to charge one joint asset to both of the creditors. Scholars also highlighted that multiple charges on one asset is only allowed if it can be divided equally to all the creditors. For instance, it is allowed to divide a piece of land and a packet of sugar to a number of creditors since the division process will not cause damage to the asset. In the situation where the division process of joint undivided asset will decrease the value of the asset, scholars still allow this practice since the creditor still has the ownership on the asset and they can claim the remaining balance from the debtor.

\section{Pledge of Joint Undivided Asset (Rahn Al- Mushā'):}

As mentioned by Al-Ma'amūrī (2015), the Shariah basis to allow the pledge of joint undivided asset are:

a. Based on the legal maxim that "everything permitted to sell is permitted to pledge as security". 
b. Possession of a pledged asset can be either physical possession or constructive possession. In case of joint undivided asset, constructive possession will be applied.

c. Scholars allow the sale of joint asset and the pledge of one asset to many creditors. Thus, the pledge of joint undivided asset is permissible.

d. The purpose of the pledge is to secure the interest of the creditor or seller (in deferred sale) which can be materialised in the pledge of joint undivided asset. Then, there is no reason why pledge of joint asset is not permissible.

\subsection{Preferred Opinion (Tarjīh):}

From the discussion above, this paper believes that all major issues in floating charge debenture are already answered. Even though floating charge debenture did not exist yet during classical Scholars' time, its characteristics were already discussed in figh literature. Thus, the justification on the permissibility of floating charge debenture is clearly elaborated in the discussion above based on the second group's opinion.

\subsection{Fiqh Adaption (Takyīf Fiqhī): Floating Charge Debenture as W'ad}

One of the characteristics of floating charge is that, it can be converted to fixed charge during liquidation. It happens in the existence of either of two contingencies; either default of payment or winding up. At that time, floating charge of the debenture would become a fixed charge upon court order requested by the creditor (Jacob, 1938).

From another perspective, this paper also suggests that, floating charge can be considered as an undertaking by the borrower to the creditor that the borrower gives consent to the creditor to seize his entire asset in the event of default. Islamic banks will exercise their right on $w^{\prime} a d$ given by the customer in the occurrence of both contingencies mentioned above.

Both $w^{\prime} a d$ with condition and floating charge debenture share the same characteristics as below:

\begin{tabular}{|l|l|}
\hline W'ad & Floating Charge Debenture \\
\hline Promisor & Debtor \\
\hline Promisee & Creditor \\
\hline Condition & $\begin{array}{l}\text { default of payment or } \\
\text { winding up }\end{array}$ \\
\hline Commitment & $\begin{array}{l}\text { To pledge all asset owned by } \\
\text { the debtor. }\end{array}$ \\
\hline $\begin{array}{l}\text { Unilaterally binding on } \\
\text { promisor }\end{array}$ & $\begin{array}{l}\text { Unilaterally binding on } \\
\text { issuer }\end{array}$ \\
\hline
\end{tabular}

Based on this fiqh adaptation, during the inception of Rahn contract and even after registration of floating charge, Rahn contract is yet to exist since there is no specific pledged asset during the inception of floating charge debenture. Therefore, Rahn contract is only established when the borrower has defaulted. At that time, floating charge is converted to the fixed charge and the pledged asset is clearly specified. In another word, floating charge debenture also can be considered as future Rahn.

It means that, with the adoption of this figh adaptation, there are no Shariah issues that are related to Rahn as mentioned by the first group above which is pledged asset to be owned in the future, uncertainty in pledged asset, multiple charges on one asset and pledge of joint undivided asset.

In terms of the enforceability of the undertaking given by the customer, SAC BNM in $157^{\text {th }}$ Meeting on $31^{\text {st }}$ March 2015 (Bank Negara Malaysia, 2015) resolved that, $w^{\prime} a d$ is unilaterally binding on the promisor if it is attached to a cause or circumstance. Then, BNM in Section 9.2 in Policy Document of $W^{\prime} a d$ also stated that, wa'd that is attached to a condition, time, price, conduct or event shall be binding on the promisor (Bank Negara Malaysia, 2017). This opinion is same with the preferred opinion in the Malīkī School which was expounded by Mālik, Ibn Al-Qāsim and Sahnūn. (Irwani Abdullah, 2010).

\section{Conclusion}

This paper found that the general concept of debenture as security (fixed and floating charge) is similar with Rahn. Based on the comparison between Rahn and debenture, the analysis shows that, out of 14 elements, similarity rate between Rahn and debenture is $79 \%$ (11 
out of 14 elements). Then, the non-similarity rate between Rahn and debenture is $14 \%$ ( 2 out of 13 elements). While, there is only $7 \%$ ( 1 element) where Rahn has an additional condition compared to debenture.

In addition, this paper provides the basis for floating charge debenture for Islamic banks in Malaysia from an Islamic perspective. It shows that, even though floating charge debenture does not fulfil the conditions of majority of classical scholars, however, it is allowed based on the opinions of contemporary Islamic scholars. Contemporary Islamic scholars play a key role in supporting Islamic banking development, shaping and guiding Islamic banking to be aligned with Shariah.

Based on the analysis that has been done, it was found that the practice of floating charge debenture as security is permissible from the Shariah perspective. In addition, floating charge debenture also can be considered as $w^{\prime}$ ad or future Rahn. Hence, further research on floating charge should be conducted to discuss the process flow, detail of transaction, special condition and requirement to meet both operational and Shariah requirements.

\section{References}

AAOIFI. (2015). Shari'ah Standards (Nov 2017). Bahrain: Dar AlMaiman for Publishing \& Distributing.

Al-Ma'amūrī, M. M. (2015). Mortgage Possesory Between Configuration Rules and The Rules of Inclusion of The Mortgage. Legal Comparative Study of Islamic Jurisprudence, 4, 369 .

- Al-Ma'anī. (n.d.). Dictionary Arabic - English. Retrieved April 28, 2018, from https://www.almaany.com/en/dict/aren/ /

- Al-Yamānī, A. H. Y. al-I. al-S. (2000). Al-Bayan fi Mazhab Imam Syafie.pdf. Beirut, Lubnan: Dar alMinhaj.

- At-Tāhūnī, Z. A. al-'Uthmānī. (1997). I'la' As-Sunan (Volume 18). Karachi, Pakistan: Idaratul Qran Wal Uloomil Islamia.

Bank Negara Malaysia. (2015). The Shariah Advisory Council of Bank Negara Malaysia (the SAC) 157th Meeting. Kuala Lumpur. Retrieved from http://www.bnm.gov.my/index.php?ch=en_about\&pg=en_sac_ updates\&ac $=473$

- Bank Negara Malaysia. (2017). Wa'd Contract Policy Document. Kuala Lumpur.

- E Finance Management. (n.d.). Floating charge. Retrieved May 1, 2018, from https://efinancemanagement.com/sources-of-finance/floatingcharge
Field Fisher Waterhouse. (2011). Fixed and Floating Security.

- Government of Malaysia. Companies Act 2016, Pub. L. No. Act 777 (2016).

- Hammād, N. (2009). Unilateral \& Bilateral Promise. In Dirasat Ma'ayir Shari'iyyah (Volume 4.2, pp. 32693396). Bahrain: AAOIFI.

- Hussīn, S. K. (2013). Rahn 'inda Arab Jahiliyyah wa Mauqif Islam minhu. Dirasat Tarikhiyyah "Adad Rabi" 'Isyrin, 14, 77-136.

- Ibnu Taymīyyah, \& Ibnu Qayyīm al-Jawzī. (1928). AlQiyas fi Syara' Islami. Cairo, Egypt: Maktabah asSalafiah wa Maktabatuha.

- Irwani Abdullah, N. (2010). Status and Implications of Promise (Wa'd) in Contemporary Islamic Banking. Humanomics, 26(2), 84-98. https://doi.org/10.1108/08288661011074891

- Jacob, F. W. (1938). The Effect of Provision for Ratable Protection of Debenture Holders in Case of Subsequent Mortgage. Harvard Law Review, 52(1), 77-127. Retrieved from http://www.jstor.org/stable/1333624

- Mansuri, M. T. (2007). Islamic Law of Contracts and Business Transactions. New Delhi: Adam Publishers \& Distributors.

- Mohammad Yusoff, M. N. (2002). Loan Recovery Through Debentures The Malaysian Banking Experience. International Islamic University Malaysia (IIUM).

Musa, T. I. (2008). Ahkam Rahn fi Syariah Islamiyah baina Nazariyah wa Tathbiq. Hebron University AlKhalil University, Palestine.

- Mustafā, I., Qādir, H. 'Abdul, Ziyāt, A. H., \& Najjār, M. 'Ali. (2004). Mujam al-Wasit (4th Editio). Egypt: Maktabah Asy-syuruq Ad-dauliah.

- Schacht, J. (1950). Origins of Muhammadan Jurisprudence.

Shariah Advisory Council BNM. (2017). Shariah Advisory Council of Bank Negara Malaysia (the SAC) 174th Meeting. Retrieved May 1, 2018, from http://www.bnm.gov.my/index.php?ch=en_about\&pg=en_sac updates\&ac $=516$

- Shīkh 'Ahmad Ashāwī. (1995). Bulghatul Salik li Aqrabul Masalik.pdf (Volume 3). Beirut, Lubnan.

- The Basel Committe. (2006). Principles for the Management of Credit Risk. IFAS Extension, 1-33. Retrieved from http://edis.ifas.ufl.edu/pdffiles/HR/HR02200.pdf

- Thomson Reuters. (n.d.-a). Fixed Charge. Retrieved April 28, 2018, from https://uk.practicallaw.thomsonreuters.com/0$107-$

5768 ? riginationContext $=$ document $\&$ transitionType $=$ Documen tItem\&contextData $=\% 28 \mathrm{sc}$. Default $\% 29 \&$ comp $=$ pluk

- Thomson Reuters. (n.d.-b). Floating charge. Retrieved April 28, 2018, from https://uk.practicallaw.thomsonreuters.com/0-1075773? transitionType $=$ Default\&contextData $=($ sc.Default $) \&$ first Page $=$ true \&bhcp $=1$

- Zhuravel, M. (2015). Fixed and Floating Charges as Security Mechanism in Corporate Finance Law in the United Kingdom. Юридична Україна, (9), 48-57. 